\title{
HUBUNGAN ANTARA ETOS KERJA, PENGETAHUAN MANAJEMEN, DAN KINERJA PROFESIONAL GURU TEKNOLOGI DI SULAWESI UTARA
}

\author{
Jimmy Waworuntu \\ Fakultas Teknik Universitas Negeri Manado \\ Kampus Universitas Negeri Manado di Tondano, Minahasa \\ Email: jwaworuntu@gmail.com
}

\begin{abstract}
ABSTRAK
Penelitian ini bertujuan untuk meneliti hubungan antara etos kerja, pengetahuan manajemen, dan kinerja profesional guru teknologi di Sulawesi Utara. Ini merupakan suatu penelitian korelasional dengan 55 guru sebagai sampel yang diambil secara acak dan proporsional dari tiga sekolah menengah kejuruan yang mewakili, yakni SMK Negeri 2 Manado, SMK Negeri 2 Bitung, dan SMK Kristen 1 Tomohon. Tiga instrumen penelitian digunakan untuk mengumpul data, yaitu kinerja profesional dan etos kerja menggunakan kuesioner, dan pengetahuan manajemen menggunakan tes. Hasil penelitian menunjukan (1) terdapat hubungan positif antara etos kerja dengan kinerja profesional, (2) terdapat hubungan positif antara pengetahuan manajemen dengan kinerja profesional, dan (3) terdapat hubungan positif antara etos kerja dan pengetahuan manajemen dengan kinerja profesional. Hasil penelitian tersebut dapat menjadi informasi yang penting bagi kepala sekolah, dinas pendidikan, dan pemerintah.
\end{abstract}

Kata kunci: kinerja profesional; etos kerja; pengetahuan manajemen; guru teknologi

\section{RELATIONSHIP BETWEEN WORK ETHIC, MANAGERIAL KNOWLEDGE, AND PROFESSIONAL PERFORMANCE OF TECHNOLOGY TEACHERS IN NORTH SULAWESI}

\begin{abstract}
This research was aimed to examine the relationship between work ethic, managerial knowledge, and professional performance of technology teachers in North Sulawesi. It was a correlational study with 55 teachers as samples, taken with random and proportional sampling from three representative vocational high schools i.e. SMK Negeri 2 Manado, SMK Negeri 2 Bitung, and SMK Kristen 1 Tomohon. Three instruments were used to collect the data, i.e. professional performance and work ethic using questionnaires, and managerial knowledge using test. The findings showed as the followings: (1) there was a positive relationship between work ethic and professional performance; (2) there was a positive relationship between managerial knowledge and professional performance; and (3) there was a positive relationship between work ethic and managerial knowledge with professional performance. Thus, the findings can be used as important information for principals, education authorities, and the government.
\end{abstract}

Keywords: professional performance; work ethic; managerial knowledge; technological teachers

\section{PENDAHULUAN}

Kinerja guru sekolah menengah kejuruan di Indonesia dikategorikan kurang dengan nilai kinerja 77,12 (Pusat Data dan Statistik Pendidikan dan Kebudayaan, 2016). Atas dasar ini, perlu dicari jalan keluar bagaimana meningkatkan kinerja guru. Berdasarkan Peraturan Menteri Negara Pendayagunaan Aparatur Negara Dan Reformasi
Birokrasi Nomor 16 Tahun 2009 Tentang Jabatan Fungsional Guru dan Angka Kredit, kinerja guru dinilai terutama dalam rangka pembinaan karier kepangkatan dan jabatan, serta untuk mencapai hasil pendidikan yang bermutu. Tilaar (2002) menjelaskan bahwa, berdasarkan laporan majalah Asianweek beberapa tahun terakhir tentang mutu pendidikan tinggi di Asia dan Australia, mutu pendidikan di Indonesia rendah dan sangat mendesak untuk 
ditingkatkan. Melihat akan hal ini, maka kinerja guru dapat menjadi perhatian utama dalam menyelesaikan masalah mutu pendidikan.

Menurut teori Gibson, yang dikutip oleh Illyas (1999), ada tiga kelompok variabel yang mempengaruhi perilaku kerja dan kinerja, yaitu variabel individu, variabel organisasi, dan variabel psikologis. Dalam penelitian ini, dipilih dua variabel penelitian yang mempengaruhi kinerja, yaitu etos kerja (kelompok variabel individu) dan pengetahuan manajemen (kelompok variabel psikologis). Kedua variabel ini boleh menjadi variabel yang bersinergi dalam mempengaruhi kinerja guru. Seseorang yang memiliki etos kerja yang tinggi memiki semangat tinggi untuk melakukan suatu pekerjaan. Akan tetapi, tanpa pengetahuan, hasil yang dicapai tidak akan maksimal.

Sehubungan dengan itu, penelitian ini bertujuan untuk melihat sejauh mana hubungan antara etos kerja, pengetahuan manajemen, dan kinerja profesional guru. Hasil penelitian akan berguna menjadi informasi yang penting bagi kepala-kepala sekolah, dinas pendidikan nasional, ataupun pihak lain yang berkepentingan sesuai perannya masing-masing dalam meningkatkan kinerja profesional guru, sehingga diharapkan mutu pendidikan pun dapat meningkat.

Perbaikan kinerja, baik untuk individu maupun kelompok, menjadi pusat perhatian dalam upaya meningkatkan kinerja organisasi (Mathis dan Jackson, 2002). Suatu organisasi tentu akan tetap ada apabila kinerja organisasi baik. Jika tidak, maka organisasi itu akan mati. Dalam bisnis, suatu perusahan akan terus merugi atau bahkan bangkrut apabila kinerja perusahaan kurang baik. Kinerja organisasi tentu tidak lepas dari kinerja individu atau kelompok yang ada di dalam organisasi. Itulah sebabnya kinerja, baik individu maupun kelompok, menjadi pusat perhatian setiap lembaga.

Apa sebenarnya kinerja itu? Mangkunegara (2005) mengemukakan bahwa kinerja adalah prestasi kerja yang dicapai seseorang dalam melaksanakan tugas sesuai dengan tanggung jawab yang diberikan kepadanya dari segi kualitas dan kuantitas. Secara kualitas menunjukkan baik buruknya seseorang melakukan pekerjaan atau tanggung jawab yang diberikan kepadanya. Hal ini sejalan dengan apa yang dikemukakan oleh George \& Jones (2008), bahwa kinerja merupakan hasil penilaian dari perilaku seseorang, yang berkaitan dengan penentuan dari seberapa baik atau buruknya seseorang telah menyelesaikan tugasnya atau melakukan pekerjaannya. Secara kuantitas menunjukkan seberapa banyak pekerjaan yang dilakukan dari apa yang menjadi tanggung jawab seseorang.

Selain kualitas dan kuantitas, kinerja mengandung unsur waktu, yakni dibatasi pada seberapa lama waktu yang diberikan kepada seseorang untuk melakukan tugasnya. Hal ini dapat dilihat dari pengertian yang dikemukakan oleh Bernadin \& Russel yang dikutip oleh Tika (2006), yakni: kinerja adalah pencatatan hasil-hasil yang diperoleh dari fungsi-fungsi pekerjaan atau kegiatan tertentu selama kurun waktu tertentu. Unsur lain yang terkandung dalam kinerja adalah usaha, kemampuan, dan kesempatan. Hal ini diungkapkan oleh Sulistiyani (2003), bahwa kinerja seseorang merupakan kombinasi dari kemampuan, usaha, dan kesempatan yang dapat dinilai dari hasil kerjanya.

Dalam dunia pendidikan, kinerja guru dapat menentukan baik buruknya mutu pendidikan. Apabila kinerja guru baik, yang berarti guru bekerja dengan sungguh-sungguh, ada motivasi, kemampuan, hasil yang baik secara kuantitas dan kualitas dalam suatu jangka waktu tertentu, maka mutu pendidikan pasti dapat ditingkatkan.

Di dalam Undang-Undang RI Nomor 14 Tahun 2005 tentang Guru dan Dosen pasal 1 ayat 1, dinyatakan bahwa guru adalah pendidik dengan tugas utama mendidik, mengajar, membimbing, mengarahkan, melatih, menilai, dan mengevaluasi peserta didik pada pendidikan anak usia dini jalur pendidikan formal, pendidikan dasar, dan pendidikan menengah. Pendidik harus memiliki kinerja sebagaimana yang tertuang dalam daftar tugas utama yang disebutkan ayat tersebut. Dalam penjelasan tentang UU Guru dan Dosen tersebut, dikatakan bahwa guru sebagai tenaga mengandung arti bahwa pekerjaan guru hanya dapat dilakukan oleh seseorang yang memiliki kualifikasi akademik, kompetensi, dan sertifikat pendidik yang sesuai dengan persyaratan untuk setiap jenis dan jenjang pendidikan tertentu.

Kompetensi yang dimaksud di sini tidak lain menjelaskan tentang tugas utama guru. Ini yang menjadi dasar penilaian kinerja guru sebagaimana yang dikatakan dalam "Penilaian Kinerja Guru," bahwa kinerja guru memiliki spesifikasi atau kriteria tertentu. Kinerja guru dapat dilihat dan diukur berdasarkan spesifikasi atau kriteria kompetensi yang harus dimiliki oleh setiap guru (Departemen Pendidikan Nasional, 2008). Selanjutnya, berdasarkan Peraturan Menteri Pendidikan Nasional Republik Indonesia Nomor 16 Tahun 2007 tentang Standar Kualifikasi Akademik dan Kompetensi Guru, standar kompetensi guru dikembangkan secara utuh dari empat kompetensi utama, yaitu: (1) pedagogik; (2) kepribadian; (3) sosial; dan (4) profesional. Keempat kompetensi tersebut terintegrasi dalam kinerja guru.

Dalam penjelasan Undang-Undang RI No. 14 Tahun 2005 tentang Guru dan Dosen, pasal 1 ayat 1 dijelaskan bahwa pengertian setiap kompetensi itu adalah sebagai berikut: (1) pedagogik adalah kemampuan mengelola pembelajaran peserta didik; (2) kepribadian adalah kemampuan kepribadian yang mantap, berakhlak mulia, arif, dan berwibawa serta menjadi teladan peserta didik; (3) profesional adalah 
kemampuan penguasaan materi pelajaran secara luas dan mendalam; (4) sosial adalah kemampuan guru untuk berkomunikasi dan berinteraksi secara efektif dan efisien dengan peserta didik, sesama guru, orang tua atau wali peserta didik, dan masyarakat sekitar. Dengan demikian, dapat diartikan bahwa kinerja profesional guru adalah unjuk kerja guru dalam menjalankan tugas keprofesionalannya berdasarkan keempat kompetensi guru, yakni kompentensi pedagogik, profesional, kepribadian, dan sosial.

Kusnadi (2007) mengemukakan pengertian etos dari Geertz (1992), yakni: etos suatu bangsa adalah sifat, watak, kualitas kehidupan mereka, moral, gaya estetis, dan suasana-suasana hati mereka. Apa yang menjadi sifat, watak, kualitas kehidupan, moral, gaya estetis, dan suasana hati tentu mempengaruhi perilaku seseorang. Misalkan saja, apabila seseorang memiliki sifat mengasihi, maka ia ingin memperlakukan orang lain dengan kasih, tidak kasar, dan ingin memperhatikan. Tapi bagaimana apabila seseorang atau kelompok yang dianggap memiliki sifat mengasihi ternyata membenci atau kasar kepada orang lain? Hal ini dikatakan bahwa dia tidak memiliki etos. Sehubungan dengan itu, Covey (2005) menjelaskan bahwa, jika seseorang secara konsisten memberikan hasil dengan cara yang berdasarkan prinsip untuk halhal yang telah mereka janjikan dan untuk apa yang diharapkan dari mereka, maka mereka memiliki "ethos."

Dalam hubungannya dengan kerja, etos akan menentukan perilaku seseorang dalam bekerja. Baik tidaknya hasil suatu pekerjaan akan ditentukan oleh sifat, watak, ataupun nilai-nilai dasar yang membentuk etos seseorang. Orang yang bertanggungjawab dalam bekerja misalnya, akan menyelesaikan pekerjaannya dengan baik dan tidak akan membiarkan begitu saja pekerjaan itu.

Pembahasan mengenai etos kerja sangat menarik dan penting, mengingat kerja adalah suatu hal yang menyangkut hidup manusia. Tuhan yang Maha Kuasa yang menciptakan langit dan bumi telah menjadikan manusia untuk bekerja agar boleh makan dan hidup.

Ajaran agama, baik Kristen maupun Islam, ataupun agama lainnya, tidak menentang hal ini. Tinggal

bagaimana seseorang dapat hidup senang atau susah,

berkelimpahan atau cukup, bahkan berkekurangan, tergantung pada keinginan dan usahanya untuk bekerja, atau dikatakan tergantung pada etos kerjanya.

Abdullah (1993) mengemukakan bahwa etos kerja berarti sikap yang mendasar tentang kerja yang ada pada diri seseorang. Etos kerja dihubungkan dengan sikap kerja seseorang. Berbicara mengenai sikap, ini sangat terkait dengan tingkah laku, sebagaimana pengertian sikap oleh Carno (1955) yang dikutip oleh Mar'at (2003), yakni: “attitude entails an existing predisposition to respon to social objects which in interaction with situational and other dispositional variables, guides and directs the overt behavior of the individual." Penjelasan ini menunjukkan bahwa sikap adalah kecenderungan bereaksi terhadap objek sosial, di mana dalam interaksi dengan situasi dan variabelvariabel lainnya membimbing dan mengarahkan tingkah laku nyata dari individu.

Jelas bahwa dengan penjelasan ini, etos kerja sangat mempengaruhi tingkah laku nyata dari individu. Etos kerja akan menuntun seseorang untuk bekerja dengan sungguh-sungguh, hemat, ingin menghargai waktu, pekerjaan, dan materi, sehingga boleh mendapatkan hasil berupa kekayaan yang berlimpah dan hidup sejahtera.

Dari beberapa rumusan etos maupun etos kerja, dapat diidentifikasi unsur-unsur psikologis yang terkandung di dalamnya, seperti sikap, nilai, sifat, kebiasaan, watak, dan lain sebagainya. Dari unsurunsur tersebut, tentu ada yang bersifat universal atau umum, yakni dapat diterima seluruh pihak dan ada yang hanya berlaku untuk sekelompok orang saja. Apabila ada unsur-unsur yang tidak diterima, inilah yang membedakan etos dari suatu bangsa dengan bangsa yang lain, suatu suku dengan suku yang lain, suatu golongan dengan golongan yang lain, suatu organisasi dan organisasi yang lain, dan juga dari suatu profesi dengan profesi yang lain.

Sehubungan dengan itu, Abdullah (2006) menjelaskan bahwa etos kerja yang disebut "etika kerja" memiliki implikasi bahwa perbedaan dalam sikap dan perilaku kerja ditentukan oleh budaya dan tradisi. Siagian (2002) memberikan pengertian etos kerja dilihat dari sudut pandang organisasi sebagai berikut: "etos kerja ialah norma-norma yang bersifat mengikat dan ditetapkan secara eksplisit serta praktekpraktek yang diterima dan diakui sebagai kebiasaan yang wajar untuk dipertahankan dan diterapkan dalam kehidupan para anggota suatu organisasi."

Bagaimana dengan pengertian etos kerja untuk profesi guru? Apabila mengambil analogi pengertian etos kerja nelayan dari Kusnadi (2007), maka etos kerja guru juga dapat diartikan dengan mudah. Disebutkan bahwa etos kerja nelayan adalah sifat, nilai, semangat, atau sikap nelayan terhadap pekerjaan mereka, yaitu melakukan penangkapan ikan di laut. Maka, etos kerja guru juga dapat diartikan sebagai sifat, nilai, semangat, atau sikap terhadap pekerjaan guru, yaitu mendidik dan mengajar. Nampaknya pengertian ini mengandung banyak aspek yang perlu disederhanakan. Apabila kembali pada pembahasan etos Kristiani atau etos Protestan yang dijelaskan Weber, maka seseorang yang memiliki etos kerja Kristiani adalah orang yang mau bekerja keras, memanfaatkan waktu hemat, dan sangat menghargai materi, menjadi kunci sukses pada peradaban barat (Sinaga, 2001). Orang-orang yang ingin bekerja keras tentu adalah orang-orang yang memiliki semangat yang tinggi untuk bekerja. Semangat ini tidak lain timbul akibat keseluruhan unsur kepribadian yang terkandung dalam diri seseorang berupa sifat, nilai, 
sikap, kebiasaan, dan lain sebagainya. Dapat dikatakan bahwa perilaku seseorang dipengaruhi oleh sejumlah variabel kepribadiannya melalui semangat kerja yang tinggi sebagai variabel perantara. Dengan demikian, etos kerja dapat diartikan secara lebih sederhana, yaitu semangat kerja dan keyakinan seseorang atau suatu kelompok.

Selanjutnya, bagaimana ciri-ciri orang yang memiliki etos kerja? Seorang motivator terkenal, Jansen Sinamo (2005), yang dijuluki sebagai Bapak Etos Indonesia, mengemukakan bahwa terdapat delapan etos kerja yang dapat memotivasi seseorang untuk berhasil dalam hidupnya. Apabila seseorang tahu dan memahami kedelapan etos kerja ini, maka akan ada semangat yang tinggi di dalam dirinya untuk kerja keras, disiplin, teliti, tekun, integritas, rasional, bertanggungjawab, dan sebagainya melalui keyakinan, komitmen, dan penghayatan atas paradigma kerja tertentu untuk melaksanakan suatu pekerjaan. Kedelapan etos kerja itu adalah:

"Etos pertama: kerja adalah rahmat.

Etos kedua: kerja adalah amanah.

Etos ketiga: kerja adalah panggilan.

Etos keempat: kerja adalah aktualisasi.

Etos kelima: kerja itu ibadah.

Etos keenam: kerja adalah seni.

Etos ketujuh: kerja adalah kehormatan.

Etos kedelapan: kerja adalah pelayanan."

Berdasarkan uraian tersebut, dapat diambil kesimpulan bahwa etos kerja adalah totalitas kepribadian seseorang yang menimbulkan semangat dan keyakinan dalam melaksanakan pekerjaan.

Setiap makhluk hidup, baik itu hewan ataupun manusia, memiliki pengetahuan. Sebagai contoh, seekor burung luri tahu cara menirukan bahasa manusia seperti selamat pagi, selamat jalan, lapar, dan lain sebagainya. Seekor lumba-lumba tahu cara berhitung ataupun melompat dalam suatu gelang api yang menyala-nyala tanpa meleset. Seekor kera tahu cara mengendarai sepeda di sebuah halaman, dan bukan di jalan raya. Hanya saja, hewan memiliki pengetahuan yang terbatas, sedangkan manusia memiliki pengetahuan yang lebih tinggi.

Suriasumantri (2001) mengatakan bahwa pengetahuan merupakan segenap apa yang diketahui manusia mengenai suatu objek tertentu. Hal ini akan menjadi sumber jawaban bagi berbagai pertanyaan atau masalah yang muncul. Apabila kita tidak memiliki pengetahuan, dapat dibayangkan bagaimana kita dapat menjalani kehidupan ini.

Pengetahuan pada hewan hanya terbatas untuk kelangsungan hidupnya, tetapi manusia dapat mengembangkan pengetahuan itu untuk mengatasi kebutuhan kelangsungan hidupnya. Manusia dapat mengembangkan pengetahuan karena dua hal, yaitu: (1) manusia memiliki bahasa yang mampu mengkomunikasikan informasi dan jalan pikiran yang melatarbelakangi informasi tersebut, dan (2) manusia memiliki kemampuan berpikir menurut suatu alur kerangka berpikir tertentu (Suriasumantri, 2006).

Ilmu merupakan semua pengetahuan yang diperoleh melalui metode ilmiah. Hal tersebut didefinisikan oleh Kemany yang dikutip oleh Fischer (1975). Selanjutnya, disebutkan bahwa metode ilmiah adalah suatu siklus induksi, deduksi, verifikasi, dan penelitian terus-menerus untuk perbaikan teori yang belum tetap atau masih bersifat tentatif.

Suriasumantri (2001) juga menguraikan mengenai ilmu yang diperoleh melalui metode ilmiah. Disebutkan bahwa gabungan antara pendekatan rasional dan empiris dinamakan sebagai metode keilmuan (Suriasumantri, 2001). Pendekatan rasional memberikan kerangka pemikiran yang koheren dan logis (berpikir deduktif), sedangkan pendekatan empiris memberikan kerangka pengujian dalam memastikan suatu kebenaran (berpikir induktif).

Manajemen merupakan suatu pengetahuan yang disebut ilmu. Hal ini karena manajemen memiliki kriteria yang diperlukan sebagai suatu ilmu. Sehubungan dengan itu, Tripathi dan Reddy (1991) menjelaskan bahwa manajemen adalah suatu ilmu karena memenuhi beberapa kriteria sebagai suatu disiplin ilmu, yaitu: (1) metode penemuan yang sistematis dan empiris; (2) informasi dapat disusun dan dianalisis; dan (3) hasil-hasil bersifat kumulatif dan dapat dikomunikasikan.

Lebih khusus lagi, Stoner dan kawan-kawan (1995) mengungkapkan bahwa manajemen adalah suatu disiplin ilmu terapan yang berhubungan dengan hasil-hasil praktis. Oleh karena itu, pengetahuan manajemen dapat diterapkan pada berbagai ragam situasi. Mempelajari teori manajemen membantu memahami proses proses penting dan memilih suatu rangkaian tindakan efektif. Di samping sebagai pengetahuan yang disebut ilmu, manajemen juga merupakan pengetahuan yang disebut seni. Hal ini diungkapkan oleh Tripathi dan Reddy (1991), bahwa manajemen juga merupakan suatu seni. Apabila ilmu mempelajari tentang "mengapa" dari suatu fenomena, maka seni mempelajari tentang "bagaimana" dari fenomena tersebut. Disebutkan bahwa seni berhubungan dengan pengertian tentang bagaimana suatu pekerjaan khusus dapat dilaksanakan. Seorang manajer secara terus menerus harus menganalisis situasi yang ada, menentukan tujuan, mencari alternatif,mengimplementasikan, mengkoordinasikan, mengendalikan dan mengevaluasi informasi, serta membuat keputusan. Oleh karena itu, ia harus memiliki keterampilan untuk menerapkan ilmu manajemen pada masalah yang dihadapinya. Dalam hal inilah manajemen merupakan suatu seni.

Kembali kepada pembahasan mengenai pengetahuan. Apa yang dibahas pada uraian terdahulu lebih pada pembahasan secara filsafat tentang pengetahuan yang menghasilkan suatu ilmu atau tidak. 
Pada sisi lain, apabila yang dibahas adalah pengetahuan yang diperoleh seseorang karena mempelajari sesuatu, maka hal ini akan berhubungan dengan teori belajar.

Teori Bloom tentang belajar menjelaskan bahwa belajar mencakup perubahan tingkah laku dalam tiga aspek (domain). Ketiga aspek tersebut adalah aspek pengetahuan (cognitive domain), aspek keterampilan (psychomotor domain), dan aspek sikap (affective domain) (Bloom, 1984). Robbin (2001) juga mengemukakan bahwa belajar telah berlangsung jika seorang individu berperilaku, bereaksi, dan menanggapi sebagai hasil pengalaman dalam suatu cara yang berbeda dengan perilaku sebelumnya.

Dapat diambil kesimpulan bahwa pengetahuan diperoleh melalui hasil belajar, dan belajar terjadi melalui interaksi dengan lingkungan ataupun berdasarkan pengalaman, serta melalui kegiatan belajar (study). Sehubungan dengan itu, Pritcharf (2009) mengungkapkan bahwa pengetahuan diperoleh melalui belajar (study). Disebutkan pula bahwa bahwa pengetahuan adalah suatu skema yang ada dalam ingatan sebagai sesuatu yang seseorang ketahui. Suatu skema berarti suatu gambaran atau bagan tentang apa yang seseorang ketahui yang dapat menjadi bahan pertimbangan baginya untuk berpikir dalam menjawab suatu pertanyaan atau menyelesaikan suatu masalah yang dihadapi.

Berdasarkan uraian di atas, dapat diambil kesimpulan bahwa pengetahuan manajemen adalah apa yang diketahui seseorang mengenai manajemen yang mencakup fungsi-fungsi perencanaan pengorganisasian.

Telah dijelaskan bahwa etos kerja adalah totalitas kepribadian seseorang yang menimbulkan semangat dan keyakinan dalam melaksanakan pekerjaan. Etos sangat mempengaruhi perilaku seseorang dalam bekerja. Semakin tinggi etos kerja seseorang, maka semakin bersemangat dan yakin orang tersebut dalam melakukan suatu pekerjaan, sehingga memperoleh hasil atau kinerja yang baik. Dengan demikian, dapat dikemukakan suatu dugaan bahwa terdapat hubungan positif antara etos kerja guru dengan kinerja profesional guru.

Pengetahuan manajemen adalah pengetahuan tentang ilmu manajemen yang membahas tentang koordinasi sejumlah kegiatan orang lain, yang mencakup perencanaan, pengorganisasian, penempatan, pengarahan, dan pengendalian. Seorang guru yang memiliki pengetahuan yang luas tentang manajemen akan membantu dirinya dalam menjalankan tugasnya dengan baik dan sangat mempengaruhi kinerjanya. Dengan demikian, dapat diduga bahwa terdapat hubungan positif antara pengetahuan manajemen dengan kinerja profesional guru.

Berdasarkan dugaan-dugaan dalam kedua paragraf di atas, dapat dirumuskan tiga hipotesis penelitian sebagai berikut: Pertama, terdapat hubungan positif antara etos kerja dengan kinerja profesional guru teknologi beberapa sekolah kejuruan di Sulawesi Utara. Kedua, terdapat hubungan positif antara pengetahuan manajemen dengan kinerja profesional guru teknologi beberapa sekolah kejuruan di Sulawesi Utara. Ketiga, terdapat hubungan positif antara etos kerja dan pengetahuan manajemen dengan kinerja profesional guru teknologi beberapa sekolah kejuruan di Sulawesi Utara.

\section{METODE}

Penelitian ini menggunakan pendekatan kuantitatif korelasional dengan model penelitiannya dapat digambarkan sebagai berikut:

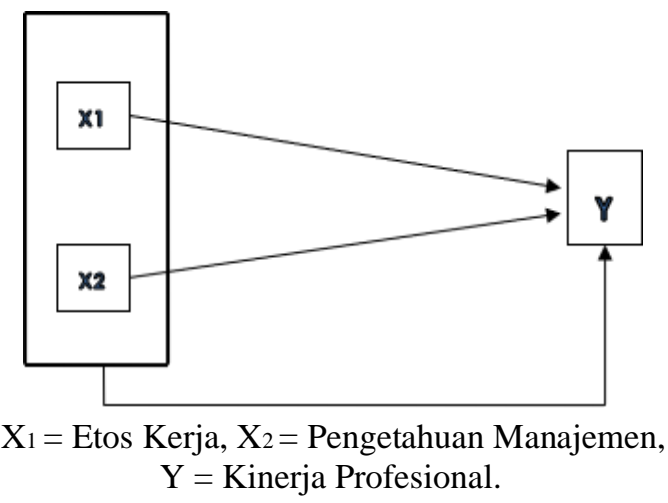

Gambar 1. Model Penelitian

Penelitian ini dilaksanakan di beberapa sekolah kejuruan di Sulawesi Utara, yakni SMK Negeri 2 Manado, SMK Negeri 2 Bitung, dan SMK Kristen 1 Tomohon dengan jumlah guru teknologi sebanyak 139 guru. Dari setiap sekolah tersebut, sampel diambil secara random dan proporsional sebanyak $40 \%$, yakni 55 orang guru.

Pengumpulan data dilakukan dengan menggunakan tiga buah instrumen penelitian dalam bentuk kuesioner dan tes. Sesuai dengan variabel yang diteliti, disusun kuesioner untuk instrumen kinerja profesional dan etos kerja, sedangkan instrumen yang digunakan untuk pengetahuan manajemen adalah berupa bentuk tes.

Pengembangan instrumen dilakukan mulai dengan perumusan butir-butirnya berdasarkan definisi operasional setiap variabel. Uji coba dilakukan kepada 30 guru sebagai subjek uji coba yang diambil secara proporsional di setiap sekolah. Data uji coba dianalisis, baik validitas dan reliabiltas, sehingga diperoleh instrumen-instrumen yang valid dan reliabel yang digunakan dalam pengumpulan data untuk pengujian hipotesis (Hinkle, 2003).

Teknik analisis data mencakup deskripsi data, pengujian persyaratan analisis (normalitas dan linieritas), dan pengujian hipotesis. 
Pengujian hipotesis satu dan dua menggunakan analisis regresi sederhana dan korelasi parsial, sedangkan pengujian hipotesis tiga menggunakan analisis regresi ganda dan korelasi ganda.

\section{HASIL PENELITIAN}

Pengujian hipotesis dilakukan setelah seluruh persyaratan analisis terpenuhi. Pengujian hipotesishipotesis tersebut dapat dijelaskan sebagai berikut:

Hipotesis pertama menyatakan bahwa terdapat hubungan positif antara etos kerja dengan kinerja profesional guru teknologi beberapa sekolah kejuruan di Sulawesi Utara. Secara statistik, hipotesis tersebut dirumuskan sebagai berikut:

$$
\begin{aligned}
& \text { Ho: } \rho_{y 1}=0 \\
& \text { Hi : } \rho_{y 1}>0
\end{aligned}
$$

Berdasarkan hasil perhitungan analisis regresi sederhana, diperoleh persamaan regresi ${ }^{\wedge} \mathrm{Y}=29,14+$ $1,05 X_{1}$. Dengan menggunakan aplikasi SPSS for Windows 17.0, pengujian signifikasi persamaan regresi tersebut dapat dilihat pada tabel berikut:

Tabel 1. ANOVA Regresi $Y$ Terhadap $X_{1}$

\begin{tabular}{lllllll}
\multicolumn{2}{l}{ Model } & $\begin{array}{c}\text { Sum of } \\
\text { Squares }\end{array}$ & Df & $\begin{array}{c}\text { Mean } \\
\text { Square }\end{array}$ & F & Sig. \\
\hline 1 & Regression & 3334,969 & 1 & 3334,969 & 89,417 & ,000(a) \\
& Residual & 1976,740 & 53 & 37,297 & & \\
\multirow{2}{*}{ Total } & 5311,709 & 54 & & & \\
& & &
\end{tabular}

a Predictors: (Constant), VAR00001

b Dependent Variable: VAR00003

Dalam tabel, untuk pengujian signifikansi terlihat bahwa harga $F$ hitung adalah 89,417 . Sedangkan harga $\mathrm{F}$ tabel dengan derajat kebebasan pembilang 1 dan penyebut 53 pada taraf signifikansi $5 \%$ dan $1 \%$ beturut-turut adalah 4,02 dan 7,12. Dengan membandingkan kedua harga $\mathrm{F}$ tersebut, maka diketahui bahwa Fhitung $>F_{\text {tabel. }}$. Hal ini menunjukkan bahwa persamaan regresi $\hat{Y}=29,14+1,05 X_{1}$ sangat signifikan.

Untuk melihat kekuatan hubungan yang diperoleh antara variabel etos kerja $\left(\mathrm{X}_{1}\right)$ dengan kinerja profesional (Y), dilakukan analisis korelasi parsial. Pengujian dengan analisis korelasi parsial dilakukan melalui dua tahap, yaitu dengan cara menghitung koefisien korelasi product moment, kemudian menghitung koefisien korelasi parsial.

\section{Tabel 2. Uji Signifikasi Korelasi Parsial $X_{1} Y$}

\begin{tabular}{lcccccc}
\multirow{2}{*}{$\begin{array}{l}\text { Korelasi } \\
\text { Antara }\end{array}$} & $\begin{array}{c}\text { Variabel } \\
\text { Kontrol }\end{array}$ & $\begin{array}{c}\text { Koefisien } \\
\text { Korelasi }\end{array}$ & $\begin{array}{c}\text { Koefisien } \\
\text { Determinasi }\end{array}$ & $\begin{array}{c}\mathrm{t} \\
\text { hitung }\end{array}$ & \multicolumn{2}{c}{$\mathrm{t}$ tabel } \\
\cline { 6 - 8 } & & & & 0,05 & 0,01 \\
\hline $\mathrm{X}_{1}$ dan Y & - & $0,792^{* *}$ & 0,63 & 9,44 & 2,0 & 2,66
\end{tabular}

\begin{tabular}{ccccccc}
$\mathrm{X}_{1}$ dan $\mathrm{Y}$ & $\mathrm{X}_{2}$ & $0,826^{* *}$ & 0,68 & 10,67 & 2,0 & 2,26 \\
\hline$* *$ & Koefisien & Korelasi sangat signifikan (thitung $>$ ttabel).
\end{tabular}

Berdasarkan uji signifikasi koefisien korelasi, terlihat bahwa korelasi product moment maupun parsial hubungan antara variabel $\mathrm{X}_{1}$ dan $\mathrm{Y}$ sangat signifikan. Dengan demikian, dari hasil pengujian tahap ini, dapat disimpulkan bahwa hipotesis pertama diterima, yaitu terdapat hubungan positif antara etos kerja dengan kinerja profesional guru teknologi beberapa sekolah kejuruan di Sulawesi Utara. Koefisien determinasi dengan $\mathrm{X}_{2}$ dikontrol sebesar $\mathrm{r}_{2}$ $=0,68$, menunjukkan bahwa $68 \%$ variasi yang terjadi pada variabel kinerja profesional (Y) dapat dijelaskan oleh variabel etos kerja $\left(\mathrm{X}_{1}\right)$ secara murni.

Hipotesis kedua menyatakan bahwa terdapat hubungan positif antara pengetahuan manajemen dengan kinerja profesional guru teknologi beberapa sekolah kejuruan di Sulawesi Utara. Secara statistik, hipotesis tersebut dirumuskan sebagai berikut:

$$
\begin{aligned}
& \text { Ho: } \rho_{y 2}=0 \\
& \text { Hi : } \rho_{y 2}>0
\end{aligned}
$$

Berdasarkan hasil perhitungan analisis regresi sederhana, diperoleh persamaan regresi $\hat{Y}=$ $142,80+1,25 \mathrm{X}_{2}$. Dengan menggunakan aplikasi SPSS for Windows 17.0, pengujian signifikasi persamaan regresi tersebut dapat dilihat pada tabel berikut:

Tabel 3. ANOVA Regresi Y Terhadap X2

\begin{tabular}{llccccc}
\multicolumn{1}{l}{ Model } & $\begin{array}{c}\text { Sum of } \\
\text { Squares }\end{array}$ & df & $\begin{array}{c}\text { Mean } \\
\text { Square }\end{array}$ & F & Sig. \\
\hline 1 & Regression & 1653,994 & 1 & 1653,994 & 23,966 &, $000(\mathrm{a})$ \\
& Residual & 3657,715 & 53 & 69,013 & & \\
& Total & 5311,709 & 54 & & &
\end{tabular}

a Predictors: (Constant), VAR00002

b Dependent Variable: VAR00003

Dalam tabel, untuk pengujian signifikansi terlihat bahwa harga $F$ hitung adalah 23,966. Sedangkan harga F tabel dengan derajat kebebasan pembilang 1 dan penyebut 53 pada taraf signifikansi $5 \%$ dan $1 \%$ beturut-turut adalah 4,02 dan 7,12. Dengan membandingkan kedua harga $\mathrm{F}$ tersebut, maka diketahui bahwa Fhitung $>$ Ftabel. Hal ini menunjukkan bahwa persamaan regresi $\hat{Y}=142,80+$ $1,25 \mathrm{X}_{2}$ sangat signifikan.

Untuk melihat kekuatan hubungan yang diperoleh antara variabel pengetahuan manajemen $\left(\mathrm{X}_{2}\right)$ dengan kinerja profesional (Y), dilakukan analisis korelasi parsial. Pengujian dengan analisis korelasi parsial melalui dua tahap, yaitu dengan cara menghitung koefisien korelasi product moment, kemudian menghitung koefisien korelasi parsial. 
Tabel 4. Uji Signifikasi Korelasi Product Moment dan Parsial $X_{2} Y$.

\begin{tabular}{lcccccc} 
Korelasi & Variabel & Koefisien & Koefisien & $\mathrm{t}$ & \multicolumn{2}{c}{$\mathrm{t}$ tabel } \\
\cline { 6 - 8 } & Kontrol & Korelasi & Determinasi & hitung & 0,05 & 0,01 \\
\hline $\mathrm{X}_{2}$ dan $\mathrm{Y}$ & - & $0,558^{* *}$ & 0,31 & 4,90 & 2,0 & 2,66 \\
$\mathrm{X}$ & & & & & & \\
$\mathrm{X}_{2}$ dan $\mathrm{Y}$ & $\mathrm{X}_{1}$ & $0,642 * *$ & 0,41 & 6,10 & 2,0 & 2,26 \\
\hline
\end{tabular}

** Koefisien Korelasi sangat signifikan (thitung >ttabel).

Berdasarkan uji signifikasi koefisien korelasi, terlihat bahwa korelasi product moment maupun parsial hubungan antara variabel $\mathrm{X}_{2}$ dan $\mathrm{Y}$ sangat signifikan. Dengan demikian, dari hasil pengujian tahap ini, dapat disimpulkan bahwa hipotesis kedua diterima, yaitu terdapat hubungan positif antara pengetahuan manajemen dengan kinerja profesional guru teknologi beberapa sekolah kejuruan di Sulawesi Utara. Koefisien determinasi dengan $\mathrm{X}_{1}$ dan $\mathrm{X}_{3}$ dikontrol sebesar $\mathrm{r}_{2}=0,41$ menunjukkan bahwa $41 \%$ variasi yang terjadi pada variabel kinerja profesional (Y) dapat dijelaskan oleh variabel pengetahuan manajemen $\left(\mathrm{X}_{2}\right)$ secara murni.

Hipotesis ketiga menyatakan bahwa terdapat hubungan positif antara etos kerja dan pengetahuan manajemen dengan kinerja profesional guru teknologi beberapa sekolah kejuruan di Sulawesi Utara. Secara statistik, hipotesis tersebut dirumuskan sebagai berikut:

$$
\begin{aligned}
& \text { Ho: } R_{y \cdot 12}=0 \\
& \text { Hi : } R_{y .12}>0
\end{aligned}
$$

Berdasarkan hasil perhitungan analisis regresi sederhana, diperoleh persamaan regresi $\hat{Y}=31,45+$ $0,93 \mathrm{X}_{1}+0,90 \mathrm{X}_{2}$. Dengan menggunakan aplikasi SPSS for Windows 17.0, pengujian signifikasi regresi ganda tersebut dapat dilihat dalam tabel berikut:

\section{Tabel 5. ANOVA Regresi Ganda}

\begin{tabular}{llccccc}
\multicolumn{2}{l}{ Model } & $\begin{array}{c}\text { Sum of } \\
\text { Squares }\end{array}$ & df & $\begin{array}{c}\text { Mean } \\
\text { Square }\end{array}$ & F & Sig. \\
\hline 1 & Regression & 4150,800 & 2 & 2075,400 & 92,962 & ,000(a) \\
& Residual & 1160,909 & 52 & 22,325 & & \\
& Total & 5311,709 & 54 & & & \\
\hline
\end{tabular}

a Predictors: (Constant), VAR00002, VAR00001

b Dependent Variable: VAR00003

Tabel 5 menunjukkan bahwa harga $\mathrm{F}$ hitung sebesar 92,96. Sedangkan harga harga F tabel dengan derajat kebebasan pembilang 2 dan penyebut 52 pada taraf signifikansi $5 \%$ dan $1 \%$ beturut-turut adalah 3,18 dan 5,08. Dengan membandingkan harga-harga tersebut, maka diketahui bahwa Fhitung $>$ Ftabel. Hal ini menunjukkan bahwa persamaan regresi $\hat{Y}=31,45+$ $0,93 X_{1}+0,90 X_{2}$ sangat signifikan.
Untuk melihat kekuatan hubungan yang diperoleh antara variabel etos kerja dan pengetahuan manajemen dengan kinerja profesional, dilakukan analisis korelasi ganda. Dari perhitungan dengan analisis korelasi ganda, diperoleh koefisien korelasi ganda sebesar $\mathrm{R}_{\mathrm{y} .12}$ $=0,884$. Pengujian signifikasi analsis korelasi ganda menunjukkan bahwa harga $\mathrm{F}$ hitung adalah 98.65 dan $\mathrm{F}$ tabel pada taraf signifikansi 5\%, dengan derajat kebebasan pembilang 3 dan penyebut 51 adalah 2,79. Apabila harga $\mathrm{F}$ hitung dan $\mathrm{F}$ tabel dibandingkan, terlihat bahwa Fhitung $>F_{\text {tabel. }}$ Hal ini menunjukkan bahwa kekuatan hubungan ganda antara variabel $\mathrm{X}_{1}$, $\mathrm{X}_{2}$, dan Y sangat signifikan.

Berdasarkan hasil analisis korelasi ganda tersebut, dapat disimpulkan bahwa hipotesis ketiga diterima, yaitu terdapat hubungan positif antara etos kerja dan pengetahuan manajemen dengan kinerja profesional guru teknologi beberapa sekolah kejuruan di Sulawesi Utara. Koefisien determinasinya adalah $\mathrm{R}_{2}=0,78$. Hal ini menunjukkan bahwa $78 \%$ variasi yang terjadi pada variabel kinerja profesional ditentukan oleh gabungan ketiga variabel bebas, yaitu etos kerja dan pengetahuan manajemen. Sisanya $22 \%$ ditentukan oleh variabel bebas lainnya.

\section{PEMBAHASAN}

Beberapa hal yang perlu dibahas dari hasil penelitian tentang kinerja profesional guru adalah sebagai berikut:

Pertama, hasil penelitian menunjukkan bahwa kinerja profesional guru cukup baik. Hal ini dapat dilihat pada Tabel 6 bahwa sebanyak 54,55\% guru memiliki skor kinerja profesional menengah (skor 149-166), 29,09\% tinggi (skor 167-178), dan 16,36\% rendah (skor 137-148).

Tabel 6. Distribusi Frekuensi Data Kinerja

\begin{tabular}{|c|c|c|c|}
\hline No. & $\begin{array}{c}\text { Interval } \\
\text { Kelas }\end{array}$ & $\begin{array}{c}\text { Frekuensi } \\
\text { Absolut }\end{array}$ & $\begin{array}{c}\text { Frekuensi } \\
\text { Relatif }\end{array}$ \\
\hline 1 & $137-142$ & 4 & 7,27 \\
\hline 2 & $143-148$ & 5 & 9,09 \\
\hline 3 & $149-154$ & 7 & 12,73 \\
\hline 4 & $155-160$ & 9 & 16,36 \\
\hline 5 & $161-166$ & 14 & 25,45 \\
\hline 6 & $167-172$ & 12 & 21,82 \\
\hline \multirow[t]{2}{*}{7} & $173-178$ & 4 & 7,27 \\
\hline & Jumlah & 55 & 100,00 \\
\hline
\end{tabular}
Profesional.

Sehubungan dengan peningkatan mutu pendidikan, maka hal ini perlu ditingkatkan lagi. Telah disinggung dalam bagian pendahuluan bahwa mutu pendidikan nasional masih rendah dan perlu ditingkatkan lagi apabila ingin sejajar dengan negaranegara tetangga lainnya, bahkan dengan negaranegara maju di dunia. Hal ini dapat dicapai dengan meningkatkan kinerja profesional guru. 
Kedua, hasil penelitian menunjukkan bahwa hubungan antara etos kerja dan kinerja profesional merupakan hubungan yang linier dan sangat signifikan. Kekuatan hubungan kedua variabel ditunjukkan dengan koefisien korelasi parsial $\mathrm{r}_{\mathrm{y} 1.23}=$ 0,854 sangat signifikan dan positif, di mana $73 \%$ variasi yang terjadi pada variabel kinerja profesional (Y) ditentukan oleh variabel etos kerja $\left(\mathrm{X}_{1}\right)$. Berdasarkan hasil penelitian ini, dapat dipahami bahwa etos kerja secara positif sangat mempengaruhi kinerja profesional guru. Etos kerja yang baik akan menghasilkan kinerja profesional yang tinggi, sementara etos kerja yang buruk akan menghasilkan kinerja profesional yang rendah. Oleh karena itu, salah satu usaha yang dapat dilakukan untuk meningkatkan kinerja profesional guru adalah dengan cara meningkatkan etos kerja mereka.

Ketiga, hasil penelitian menunjukkan bahwa hubungan antara pengetahuan manajemen dan kinerja profesional merupakan hubungan yang linier dan sangat signifikan. Kekuatan hubungan kedua variabel ditunjukkan dengan koefisien korelasi parsial $\mathrm{r}_{\mathrm{y} 2.13=}$ 0,665 sangat signifikan dan positif, di mana $44 \%$ variasi yang terjadi pada variabel kinerja profesional (Y) ditentukan oleh variabel pengetahuan manajemen $\left(\mathrm{X}_{2}\right)$. Berdasarkan hasil penelitian ini, dapat dipahami bahwa pengetahuan manajemen secara positif sangat mempengaruhi kinerja profesional guru. Oleh karena itu, salah satu usaha yang dapat dilakukan untuk meningkatkan kinerja profesional guru adalah dengan cara meningkatkan pengetahuan manajemen mereka.

Keempat, hasil penelitian menunjukkan bahwa hubungan antara etos kerja dan pengetahuan manajemen dengan kinerja profesional guru sangat signifikan. Kekuatan hubungan tersebut ditunjukkan dengan koefisien korelasi ganda $\mathrm{R}_{\mathrm{y} .123}=0,92$ sangat signifikan dan positif, di mana $85 \%$ variasi yang terjadi pada kinerja profesional guru ditentukan oleh etos kerja dan pengetahuan manajemen. Hasil ini menunjukkan bahwa etos kerja dan pengetahuan manajemen memberikan pengaruh yang cukup besar terhadap kinerja profesional guru. Pengaruh tersebut sangat bersinergi, mengingat guru yang memiliki etos kerja dan memiliki pengetahuan manajemenakan melakukan tugas dengan baik dan tepat sehingga menghasilkan kinerja yang maksimal. Meskipun guru memiliki etos kerja yang tinggi dan sangat bersemangat dalam melakukan tugasnya, tetapi tanpa pengetahuan manajemen, maka ia tidak dapat melaksanakannya dengan tepat dan cepat sehingga hasil kinerjanya pun tidak maksimal.

\section{SIMPULAN}

Beberapa kesimpulan yang dapat diambil dari hasil penelitian yang dilaporkan adalah sebagai berikut:

Pertama, terdapat hubungan positif antara etos kerja dengan kinerja profesional guru teknologi beberapa sekolah kejuruan di Sulawesi Utara. Hal ini menunjukkan bahwa etos kerja mempengaruhi kinerja profesional guru. Dengan demikian, dapat dikatakan bahwa apabila etos kerja tinggi, maka kinerja profesional guru akan tinggi. Begitu pula sebaliknya, yaitu apabila etos kerja rendah, maka kinerja profesional guru akan rendah.

Kedua, terdapat hubungan positif antara pengetahuan manajemen dengan kinerja profesional guru teknologi beberapa sekolah kejuruan di Sulawesi Utara. Hal ini menunjukkan bahwa pengetahuan manajemen mempengaruhi kinerja profesional guru. Dengan demikian, dapat dikatakan bahwa apabila pengetahuan manajemen tinggi, maka kinerja profesional guru akan tinggi. Begitu pula sebaliknya, yaitu apabila pengetahuan manajemen rendah, maka kinerja profesional guru akan rendah.

Ketiga, terdapat hubungan positif antara etos kerja dan pengetahuan manajemen dengan kinerja profesional guru teknologi beberapa sekolah kejuruan di Sulawesi Utara. Hal ini menunjukkan bahwa etos kerja dan pengetahuan manajemen secara bersamasama mempengaruhi kinerja profesional guru. Semakin tinggi etos kerja dan pengetahuan manajemen, maka semakin tinggi pula kinerja profesional guru.

Berdasarkan hasil dan kesimpulan peneliltian, diungkapkan beberapa implikasi penelitian sebagai berikut:

Pertama, hasil penelitian menunjukkan bahwa kinerja profesional guru cukup baik karena paling banyak berkisar pada kelompok menengah. Hal ini memberikan impilkasi bahwa kinerja profesional tersebut belum memuaskan dan perlu ditingkatkan lagi dalam rangka meningkatkan mutu pendidikan. Peningkatan mutu pendidikan sekarang ini menjadi perhatian serius bagi seluruh pihak, baik pemerintah, swasta, maupun masyarakat. Hal ini dapat diwujudkan apabila kinerja profesional guru dapat ditingkatkan. Dengan demikian, jelas bahwa peningkatan kinerja profesional guru akan membawa dampak yang sangat berarti bagi peningkatan mutu pendidikan.

Kedua, adanya hubungan antara etos kerja, pengetahuan manajemen, dan kinerja profesional guru memberikan implikasi bahwa usaha untuk meningkatkan kinerja profesional guru dapat dilakukan dengan cara menumbuhkan etos kerja dan meningkatkan pengetahuan manajemen mereka.

Ketiga, adanya hubungan antara etos kerja, pengetahuan manajemen, dan kinerja profesional guru memberikan implikasi bahwa hasil penelitian ini memperkuat teori tentang hubungan antara etos kerja, pengetahuan, dan kinerja. Di lain sisi, adanya hubungan tersebut menambah khasanah ilmu pengetahuan secara rinci dan lebih khusus lagi.

Kemudian, hasil penelitian ini memberikan informasi kepada pemerintah, pimpinan sekolah, guru, dan pihak lain yang berkepentingan dengan guru tentang apa yang perlu diperhatikan dalam 
meningkatkan kinerja profesional guru. Contohnya, secara langsung, kepala sekolah memiliki peranan penting untuk menumbuhkan etos kerja guru dan meningkatkan pengetahuan manajemen guru, sehingga kinerja profesional guru dapat meningkat.

Keempat, dikarenakan adanya pengaruh lain sebesar $15 \%$ yang belum diteliti di dalam penelitian ini, maka hal ini memberikan implikasi bahwa pengaruh lain tersebut perlu diteliti. Pengaruh tersebut mungkin berupa faktor internal, mungkin juga faktor eksternal dari guru. Beberapa faktor yang diduga banyak mempengaruhi adalah faktor eksternal berupa belum meratanya kesejahteraan guru, kurangnya pengawasan dari pimpinan sekolah ataupun dari pemerintah, dan lain-lain. Hal ini dapat menjadi informasi bagi para peneliti untuk diteliti.

Kelima, Indonesia termasuk negara sedang berkembang yang masih belum baik mutu pendidikannya. Sama halnya dengan negara-negara berkembang lainnya di dunia, mutu pendidikan merupakan suatu masalah yang perlu mendapat perhatian. Memperbaiki kinerja guru adalah salah satu alternatif pemecahannya. Dengan demikian, apa yang menjadi implikasi lokal merupakan implikasi internasional juga. Sesuai dengan hasil penelitian ini, maka kinerja profesional guru di negara-negara berkembang dapat diperbaiki melalui etos kerja dan pengetahuan manajemen guru.

Keenam, hubungan positif etos kerja dan pengetahuan manajemen terhadap kinerja profesional dalam bidang pendidikan merupakan masalah umum yang menjadi masalah dalam bidang lain juga. Dalam bidang bisnis, untuk memperbaiki kinerja karyawan suatu perusahaan, maka etos kerja dan pengetahuan manajemen perlu ditingkatkan.

\section{DAFTAR PUSTAKA}

Abdullah, B. (2006). Menanti Kemakmuran Negeri: Kumpulan Esai tentang Pembangunan Sosial Ekonomi Indonesia. Jakarta: PT Gramedia Pustaka Utama.

Abdullah, T. (ed.) (1993). Agama, Etos Kerja dan Perkembangan Ekonomi. Jakarta: LP3ES.

Bloom, B. S., Engelhart, M. D., Furst, E. J., Hill, W. H., \& Krathwohl, D. R. (1956). Taxonomy of Educational Objectives: The Classification of Educational Goals, Handbook 1: Cognitive Domain.

Covery, S. R. (2005). The 8th Habit: Melampaui Efektivitas Menggapai Keagungan. PT Gramedia Pustaka Utama.

Departemen Pendidikan Nasional (2008). Penilaian Kinerja Guru.

George, J. M., \& Jones, G. R. (2008). Understanding and Managing Organizational Behavior (5th ed.). Pearson.

Hinkle, D. E., Wersma, W., \& Jurs, S. G. (2003).
Applied Statistics for the Behavior Sciences (5th ed.). Houghton Mifflin Harcourt.

Presiden Republik Indonesia. (2005). UndangUndang Republik Indonesia Nomor 14 Tahun 2005 tentang Guru dan Dosen.

Pusat Data dan Statistik Pendidikan dan Kebudayaan. (2016). Analisis Sumber Daya Manusia Pendidikan Dasar dan Menengah Tahun 2015/2016.

Kusnadi. (2007). Jaminan Sosial Nelayan. PT LKiS Pelangi Aksara.

Mangkunegara, A. A. A. P. (2005). Evaluasi Kinerja SDM. Bandung: Tiga Serangkai.

Mar'at. (2003). Sikap Manusia: Perubahan serta Pengukurannya. Ghalia Indonesia.

Mathis, R. L. (2002). Manajemen Sumber Daya Manusia (9th ed.). Jakarta: Salemba Empat.

Peraturan Menteri Negara Pendayagunaan Aparatur Negara dan Reformasi Birokrasi. (2009). Jabatan Fungsional Guru dan Angka Kreditnya. Retrieved from http://simpuh.kemenag.go.id/regulasi/permenpa n_16_09.pdf

Pritchard, A. (2009). Ways of Learning: Learning Theories and Learning Styles in the Classroom (2nd ed.). Routledge.

Robbins, S. P. (2001). Organizational Behavior: Concepts, Controversies, Applications (9thed.). Prentice Hall.

Siagian, S. P. (2002). Kiat Meningkatkan Produktivitas. Jakarta: Rineka Cipta.

Sinaga, M. L., \& Darmaputera, E. (2001). Pergulatan Kehadiran Kristen di Indonesia: Teks-teks Terpilih Eka Darmaputra. Jakarta: BPK Gunung Mulia.

Sinamo, J. H. (2005). Etos Kerja Profesional: Navigator Anda Menuju Sukses. Jakarta: Institut Dharma Mahardika.

Stoner, J. A. F., Freeman, R. E., \& Gilbert Jr., D. R. (1995). Management. London: Prentice Hall.

Sulistiyani, A. T., \& Rosidah. (2003). Manajemen Sumber Daya Manusia: Konsep, Teori dan Pengembangan dalam Konteks Organisasi Publik. Yogyakarta: Graha Ilmu.

Suriasumantri, J. S. (2001). Filsafat Ilmu: Sebuah Pengantar Populer. Jakarta: Pustaka Sinar Harapan.

Suriasumantri, J. S. (2006). Ilmu Dalam Perspektif. Jakarta: Yayasan Pustaka Obor Indonesia.

Tika, H. M. P. (2006). Budaya Organisasi dan Penigkatan Kinerja Perusahaan. Jakarta: Bumi Aksara.

Tilaar, H. A. R. (2002). Membenahi Pendidikan Nasional. Jakarta: Rineka Cipta.

Tripathi, P. C., \& Reddy, P. N. (1991). Principles of Management (2nd ed.). McGraw-Hill Company Limited. 